\title{
Theoretical and Experimental Behaviour of Single Slope Solar Still Heat Transfer
}

\author{
Yeo Kiam Beng*, Ong Cheah Meng and Seock-Sam Kim \\ Material and Mineral Research Unit, Faculty of Engineering, \\ Universiti Malaysia Sabah, Kota Kinabalu, Sabah, Malaysia.
}

\begin{abstract}
This paper is aimed to investigate the heat transfer behaviours of a single slope solar still under the tropical climate at Kota Kinabalu city, Malaysia. Both theoretical and experimental approaches has been performed and discussed. The theoretical heat transfer principal behaviour of the single slope solar still is successfully modelled based on the heat exchange processes of three major components of the solar still (glass cover, seawater and basin) and its surroundings. The theoretical model developed has shown to predict closely the experimental trend of the heat transfer processes of the solar still system. Outdoor experiment is also carried out under the Kota Kinabalu, Sabah, climate that showed a maximum output of 1.4 litres per day of clean distilled water and has achieved a high and consistent system temperature of $80.0^{\circ} \mathrm{C}$. In comparison with the theoretical and the experimental results, the theoretical model is found to closely predict the solar still behaviours at the early hours in the morning where the solar irradiance is intense and consistent.
\end{abstract}

Keywords: Single slope solar still, Solar Thermal Energy, Seawater

\section{Introduction}

The solar still is by far the most viable and versatile method for seawater desalination exploration studies [1]. The primitive form of distilling water using the solar still concept is by driving the evaporation of water from the humid soil using the sunlight, and the water vapour is then cool down on a condenser film [2]. Modern solar still with trapezium prism shape or pyramidal shape are very common nowadays, while there are other unique solar stills such as the inverted solar still, vertical solar still, tilted wick type solar still and others [3-5]. In general, the geometric constraints and nature of operation of the solar still are the critical control parameters for producing an output optimum quality and quantity of the clean water.

In functionality, the active solar still depends on the external heating elements to achieve consistent output, while the passive solar still do not. It has been observed that the active solar still yield higher productivity due to the additional thermal resources [6]. However, the complex design of the active solar still requires a longer fabrication and assembly period and also higher production and maintenance cost than the passive solar still [7]. Researchers [8-11] throughout are found to pursue the improvement of the efficiency of solar still by some form of modifications or add-ons.

The factors that affect the output of a solar still are identified as the environmental and the design factors. Environmental factors are very subjective and exclusive only for a particular

\footnotetext{
* Corresponding author. Tel.: +088-320000 (3236)

E-mail address: nooryeo@ums.edu.my
}

Manuscript History:

Received 6 February, 2017, Revised 21 March, 2017, Accepted 28 March, 2017, Published 28 April, 2017

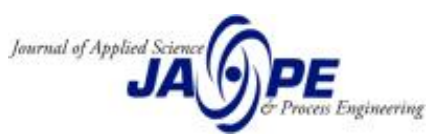


experimental location and composition of water source, which limits the proper direct comparison between them [12-16]. On the other hand, researchers [17] studied the effect of seawater depths in the solar still basin and concluded that the decreased of seawater depth in the basin led to the increase in output, which is consistent with the heat transfer and mass-flow rate of the water. This finding is also in agreement with other researches [18,19]. Furthermore, [20] and [21] both found that the orientation of the slope angle depends on the latitude angle of the place, and for locations in the northern hemisphere, the solar still must be facing the south and vice-versa for southern hemisphere.

The efficiency of a passive solar still is defined as the effectiveness of the solar still, in percentage, to utilise the solar irradiance from the sunlight in heating the brackish water in the basin for evaporation at a given surface area. Table 1 listed the efficiencies of different types of passive solar still from the past researchers.

Table 1. Efficiencies of different solar still design

\begin{tabular}{|l|c|c|}
\hline \multicolumn{1}{|c|}{ Authors } & Solar Still Type & Efficiency \\
\hline Phadatare and Verma, 2007 [22] & Single slope solar still & $34 \%$ \\
\hline Taamneh and Taamneh, 2012 [23] & Pyramidal solar still & $30 \%$ \\
\hline Ismail, 2009 [24] & Hemispherical solar still & $33 \%$ \\
\hline Abdullah, 2013 [25] & Stepped solar still & $48 \%$ \\
\hline Dashtban and Tabrizi, 2011 [10] & Weir cascade solar still & $47 \%$ \\
\hline
\end{tabular}

From Table 1, it is observed that the range of efficiency of passive solar stills is within $30 \%$ to $50 \%$. Although the variation between different types of solar still is notable, however, the efficiencies are a very dependent on the geographical location, weather conditions, and the design of the solar still. The single slope solar still efficiency of approximately $35 \%$ of the simplest design could be the maximum it could achieved.

The contribution and challenge that motivated this research topic is to be able to combine the two resources, solar energy and seawater, which are in such a gigantic abundance (practically free) could be integrated to a very simple solar still (inexpensive) to produce yet another life threatening basic need, the clean water, for consumption would be an unparalleled cause for the humanity. The aim of this paper is to present the study of heat transfer behaviour of the single slope solar still theoretical and experimental approaches under the Kota Kinabalu, Sabah, Malaysia climate.

\section{Theoretical Model}

All the heat transfer processes of the single slope solar still system involves the interaction of various mediums and different material properties, such as the basin, seawater, humid air in the solar still, the glass cover and the surroundings. The ability of each of these mediums to absorb and transmit heat energies is critical to define the generic structure of the theoretical model.

The absorptivity term used in this modelling is referred to the ability of a material to absorb the radiation heat energy from another source or medium. The humidity inside the solar still contains the water vapours evaporated from the seawater. The saturated and humid air trapped (lower in density compared to solids and liquids) inside the limited space of the solar still experiences fast heat exchange processes. With the low absorptivity compared to the rest of the mediums, practically all the heat energy emitted from the seawater is transmitted to the glass cover [26,27]. In addition, the remaining negligible heat energy absorbed by the humid air is transmitted to the glass cover. 
Therefore, this humid air medium is neglected in the heat transfer theoretical modelling of the solar still.

The heat transfer model for the single slope solar still is developed by considering the following components: the basin, the seawater and the glass cover. Each of these components behaves as a subsystem undergoing heat transfer process equilibrium relation. Hence, each of the sub-system would generate a rate of heat energy process equilibrium relation or equation. These process equilibrium equations are based on the average temperature of each separate components of the solar still. Before the derivation of the mathematical model, the following assumptions are made:

a) The volume of seawater in the solar still basin is maintained at a constant level.

b) There is no vapour leakage in the solar still.

c) The heat capacity of the insulation (well insulated) and glass cover (thin enough) are negligible.

d) No temperature gradients are anticipated between the air-to-glass-to-vapour mediums and as well as the through seawater depth in the basin. Through thickness is also considered thin enough for the rate of heat transfer to be immediate and so negligible thermal gradient exists.

e) Film type condensation occurs at the glass cover.

As a result, the respective rate of heat transfer processes for each of the component of the solar still system is derived as (1), (2) and (3). The Figure 1 also illustrates the various heat transfer quantities in the single slope solar still.

Glass cover:

$$
A_{g} a_{g} G+A_{w}\left(q_{r w}+q_{c w}+q_{e v p}\right)=A_{g}\left(q_{r g}+q_{c g}\right)
$$

Seawater:

$$
A_{w} a_{w} G+A_{b} q_{t b}=(M C)_{w} \frac{d T_{w}}{d t}+A_{w}\left(q_{r w}+q_{c w}+q_{\text {evp }}\right)
$$

Basin:

$$
A_{b} a_{b} G=A_{b}\left(q_{t b}+q_{\text {loss }}\right)
$$

Where $A_{b}, A_{g}$ and $A_{w}$ are the surface area for the basin, glass cover and seawater $\left(\mathrm{m}^{2}\right) ; a_{b}, a_{g}$ and $a_{w}$ are the absorptivity constants of the basin, glass cover and seawater; $G$ is the solar irradiance $\left(\mathrm{W} / \mathrm{m}^{2}\right)$; while $q_{r w}, q_{c w}, q_{e v p}, q_{r g}, q_{c g}, q_{t b}$ and $q_{l o s s}$ are the rate of heat transfer for a given surface area or heat flux for the seawater radiation process, seawater convection process, seawater evaporation process, glass cover radiation process, glass cover convection process, and total basin heat transfer and heat loss $\left(\mathrm{W} / \mathrm{m}^{2}\right) ;(M C) w$ is the seawater heat capacity rate per unit area $\left(\mathrm{J} / \mathrm{m}^{2} .{ }^{\circ} \mathrm{C}\right)$ for evaporation, and finally the $T_{w}$ is the seawater temperature $\left({ }^{\circ} \mathrm{C}\right)$. 


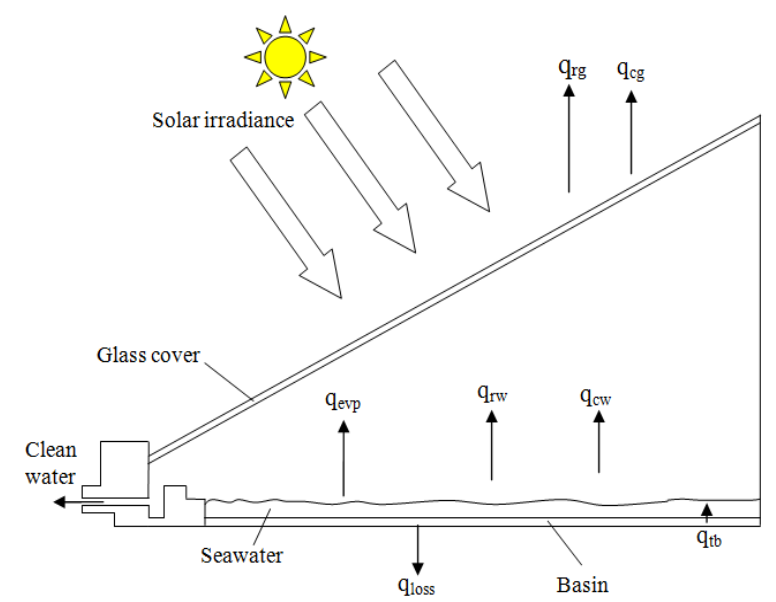

Figure 1. Interaction of Energy quantities in single slope solar still.

\subsection{Glass Cover Heat Transfer Coefficients}

The relationship between the surface area of glass cover, the surface area of water in the basin and the area of basin are as in (4) and (5). The heat transfer rates for the glass cover mentioned in (3) can be further elaborated by introducing the overall glass cover heat transfer rate, $q_{t g}$ as in (6).

$$
\begin{gathered}
A_{w}=A_{b} \\
A_{g}=A_{b} \sec \theta \\
q_{t g}=q_{r g}+q_{c g}=\left(h_{r g}+h_{c g}\right)\left(T_{g}-T_{a}\right)
\end{gathered}
$$

Where $\theta$ is the slope angle (rad), $q_{t g}, q_{r g}, q_{c g}$ are the total radiation and convection of glass cover heat flux $\left(\mathrm{W} / \mathrm{m}^{2}\right), h_{t g}, h_{r g}$ and $h_{c g}$ are the total radiation and convection of glass cover heat transfer coefficient $\left(\mathrm{W} / \mathrm{m}^{2}{ }^{\circ} \mathrm{C}\right)$, while $T_{g}$ and $T_{a}$ are the glass cover and the ambient (outside solar still) temperatures $\left({ }^{\circ} \mathrm{C}\right)$.

\subsection{Basin Heat Transfer Coefficients}

The heat energy is initially transferred from the solar still basin to the seawater and then finally to the glass cover. The (7) and (8) illustrate the relationship of total basin heat flux, $q_{t b}\left(\mathrm{~W} / \mathrm{m}^{2}\right)$, and the basin heat flux loss, $q_{\text {loss }}\left(\mathrm{W} / \mathrm{m}^{2}\right)$ with respect to the total basin heat transfer coefficient, $h_{t b}$ $\left(\mathrm{W} / \mathrm{m}^{2} .{ }^{\circ} \mathrm{C}\right)$ and the basin heat loss coefficient, $h_{\text {loss }}\left(\mathrm{W} / \mathrm{m}^{2} .{ }^{\circ} \mathrm{C}\right)[28,29]$, respectively.

$$
\begin{gathered}
q_{t b}=h_{t b}\left(T_{b}-T_{w}\right) \\
q_{\text {loss }}=h_{\text {loss }}\left(T_{b}-T_{a}\right)
\end{gathered}
$$




\subsection{Seawater Heat Transfer Coefficients}

The radiation, convection, and evaporation processes took place when the heat energy is transferred from the seawater to the glass cover of the solar still. The total seawater heat flux, $q_{t w}$ $\left(\mathrm{W} / \mathrm{m}^{2}\right)$ is also represented by $(\mathbf{9})$ with $h_{t w}$ as the total seawater heat transfer coefficient $\left(\mathrm{W} / \mathrm{m}^{2} .{ }^{\circ} \mathrm{C}\right)$.

$$
q_{t w}=q_{r w}+q_{c w}+q_{e v p}=h_{t w}\left(T_{w}-T_{g}\right)
$$

\subsection{Heat Transfer Temperature Governing Equation}

All the heat transfer rates defined are substituted into the (1), (2) and (3), respectively. By solving these three equations with the initial condition when $t=0 \mathrm{~s}, T_{w}=T_{w 0}$ and $T_{g}=T_{g 0}$, the governing equations for the system temperatures yield:

$$
\begin{gathered}
T_{g}=\frac{a_{g} G \sec \theta+h_{t g} T_{a} \sec \theta+h_{t w} T_{w}}{h_{t g} \sec \theta+h_{t w}} \\
T_{b}=\frac{a_{b} G+h_{t b} T_{w}+h_{\text {loss }} T_{a}}{\left(h_{t b}+h_{\text {loss }}\right)} \\
T_{w}=\frac{A_{b} f(t)}{z(M C)_{w}}[1-\exp (-z t)]+T_{w 0} \exp (-z t)
\end{gathered}
$$

\subsection{Critical Clean Water Mass and Solar Still Efficiency}

The mass flow rate of the evaporated seawater, $m_{\text {evp }}(\mathrm{kg} / \mathrm{s})$ and the instantaneous efficiency, $\eta$ of solar still is also determined by using the evaporation heat flux of seawater in (13) and (14), respectively, given that $h_{f g}$ is the latent heat of evaporation $\left(\mathrm{kJ} / \mathrm{kg} .{ }^{\circ} \mathrm{C}\right)$.

$$
\begin{gathered}
\dot{m}_{\text {evp }}=\frac{h_{e v p}}{h_{f g}}\left(T_{w}-T_{g}\right) \\
\eta=\frac{q_{\text {evp }}}{G}=\frac{h_{\text {evp }}\left(T_{w}-T_{g}\right)}{G}
\end{gathered}
$$

\section{Experiment}

The performance of a single slope solar still is heavily dependent on the environmental factors, and the design factors. Outdoor experiments are crucial for providing initial boundary, input data, and as well as actual physical parameter values necessary for the optimisation of the single slope solar still under the local climate. 


\subsection{Solar Still Design}

The slope angle of the solar still is a critical design parameter for determining how effective the condensate water vapour on the glass cover will flow and collected. The key factor in determining the slope angle of the solar still lies upon the latitude angle of the experimental location [20,21]. At the Kota Kinabalu, Sabah, Malaysia, the latitude angle is $5.97^{\circ} \mathrm{N}$. Based on this latitude value, the optimum value of $6^{\circ}$ is determined.

The base area for the prototypes is kept constant $\left(0.25 \mathrm{~m}^{2}\right)$ with both length and width of the prototype base $50.0 \mathrm{~cm}$ each. The single slope solar still basin is made from a $1 \mathrm{~mm}$ thick stainless steel sheet. The interior of the solar still is painted flat black to ensure a non-reflective, dark and smooth surface. Two inch thick polystyrene acting as an excellent heat insulator are bonded to all the four sides and bottom of the solar still as insulation. Clear glass with $2 \mathrm{~mm}$ thick is used as the top cover for the solar still. The Figure 2 illustrates solar still prototype.

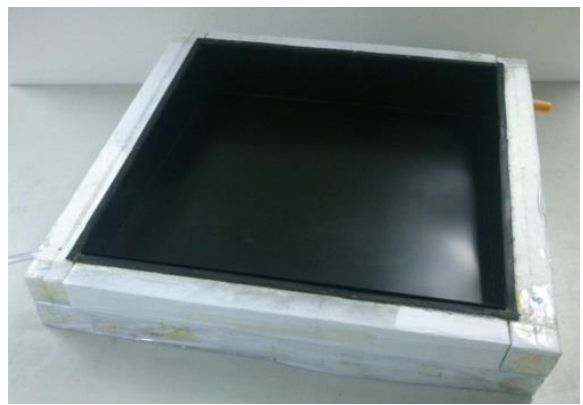

Figure 2. Fabricated single slope solar still.

\subsection{Experiment Setup}

In the experiment, a single slope solar still with $6^{\circ}$ slope angle is arranged to face the true south

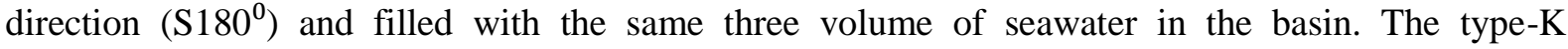
thermocouples, connected to data logger, are installed on the solar still to measure the seawater temperature $\left(T_{w}\right)$, the glass cover temperature $\left(T_{g}\right)$ and the ambient temperature $\left(T_{a}\right)$. The solar irradiance $(G)$ is recorded by using a conventional weather data logger.

The solar still is tested on a wide open area to avoid shadow from trees or buildings (Figure 3). Airtight water container is assigned to the solar still to collect the clean water produced. The mass of the collected clean water $(M)$ are recorded at every hour interval. The duration of the experiment is set between 0800 hour and 1800 hour where sunlight is available. The time before 0800 hour and after 1800 hour are not considered as there is no significant heat transfer behaviour observed. According to [30], simple passive solar still like single slope solar still used in this paper would not produce any distillate after sunset as it could not attained enough heat energy without constant heat source such as sunlight. The objective of the experiment is to establish an exclusive realistic data for the heat transfer behaviour of the solar still. In the next section, experimental findings on the effect of local climate to the optimization of the single slope solar still will be presented. 


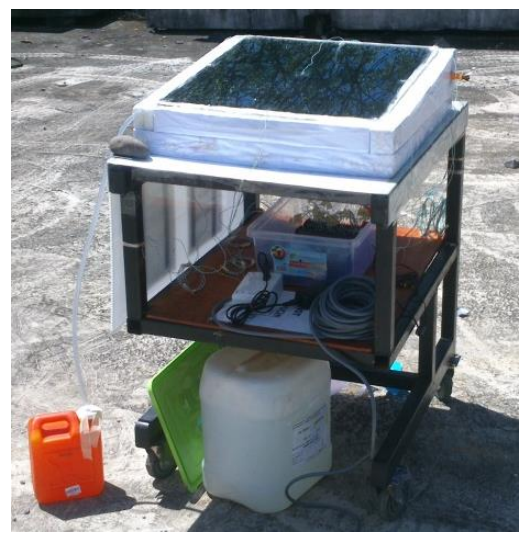

Figure 3. Single slope solar still in outdoor experiment.

\subsection{Average Solar Irradiance}

The city of Kota Kinabalu, Sabah, Malaysia, is blessed with tropical climate that often comes with a good amount of consistent sunshine. The solar irradiance represents the radiation intensity of sunlight for a given unit area is defined in Watts per meter square.

Figure 4 shows the average hourly solar irradiance of sunny days recorded at the experimental site by using conventional weather data logger. On an average sunny day, the solar irradiance at 0800 hour could start from as high as $1000 \mathrm{~W} / \mathrm{m}^{2}$. As the day moves on, the solar irradiance gradually increase to achieve a maximum value of approximately $1,250 \mathrm{~W} / \mathrm{m}^{2}$ at around 1230 hour. Thereafter, the solar irradiance remains consistent for another two hours before it starts to decrease gradually. There are as much as eight hours of solar irradiance equal or greater than the nominal irradiance (1000 $\mathrm{W} / \mathrm{m}^{2}$ ). This strong and consistent solar irradiance is particularly an excellent heat energy source for the operation of single slope solar still.

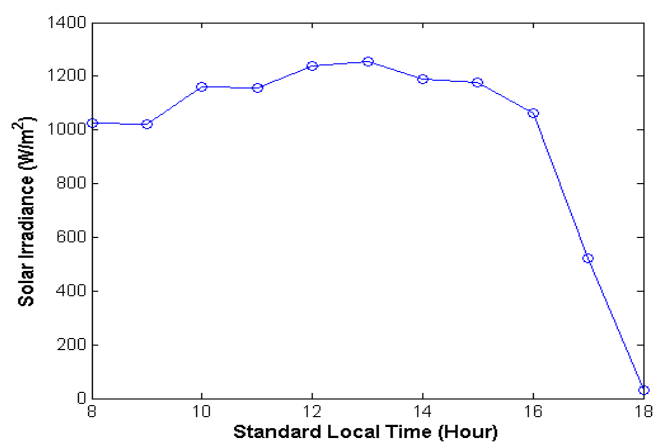

Figure 4. Relationship between average solar irradiance, $G$ and standard local time.

\subsection{Average Ambient Temperature}

The average ambient temperature, $T_{a}$ represents the boundary condition of the solar still. The rate of condensation of water vapour trapped inside the solar still depends on the temperature gradient between ambient temperature and glass cover temperature, $T_{g}$. The Figure 5 shows the average ambient temperature recorded against the standard local time.

It is observed that the ambient temperature recorded lies within $30^{\circ} \mathrm{C}$ to $33^{\circ} \mathrm{C}$. Starting from 0800 hours in the morning, the temperature begins to rise steadily until it reached a maximum of $33.1^{\circ} \mathrm{C}$ at noon 1200 hours. Thereafter, it fluctuates between $32.5^{\circ} \mathrm{C}$ and $33^{\circ} \mathrm{C}$ for the next four hours 
and decreases steadily back to $30.2^{\circ} \mathrm{C}$ at the end of the day. This type of bell-shaped temperature curve is a nominal behaviour in the equatorial countries with tropical climate.

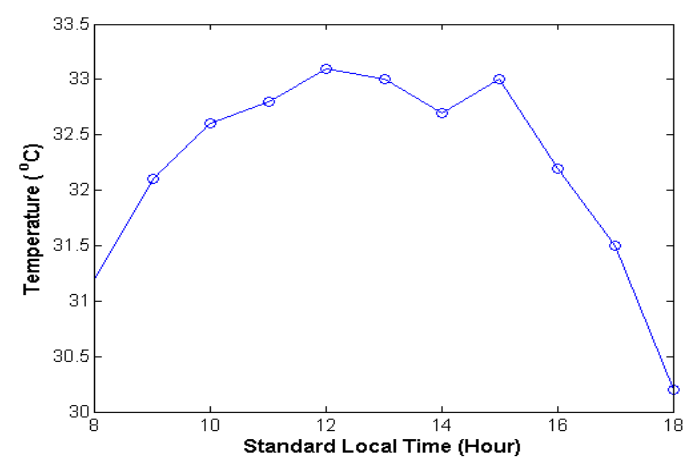

Figure 5. Relationship between average ambient temperature, $T_{a}$ and standard local time.

\section{Result and Discussion}

The working principle of the single slope solar still is identified and established to relate to heat transfer processes between the basin, seawater and glass cover. From the theoretical model and experimental result, comparison is elaborated to further correlate the optimization of solar still for developing a better prediction model.

\subsection{Optimised Average Glass Cover Temperature}

Figure 6 illustrates the comparison of theoretical and experimental average glass cover temperature on an average day. The comparison between the predictions of the analytical model, and that of the experimental result showed a similarity in their characteristic trend. At the initial stage, the theoretical model closely predicted the average glass cover temperatures for the first three hours. However, from the fourth hour onwards an over predicted result with ever increasing deviation by the each hour. The error percentage occurs at the twelve o'clock is $3.7 \%$, followed by $8.2 \%, 10.0 \%$, $13.7 \%, 25.4 \%, 52.0 \%$ and finally ended with $60.9 \%$.

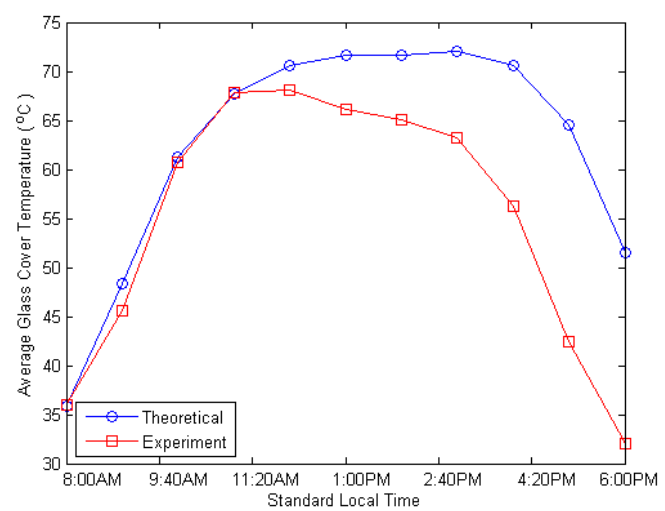

Figure 6. Theoretical and experimental comparison of average glass cover temperature, $T_{g}$.

In other words, the actual heat dissipated from the glass cover during the experiment has been more severe when the solar irradiance is decreasing at the later hours of the day, than what is predicted 
by the theoretical model. This is attributed to the less or far more varied distribution of solar irradiance, during the aftermath of the noon hours as compared to the morning hours with far more uniform and intense irradiance distribution. Another reason is the possible lagging of the theoretical prediction attributed to idealized overall glass cover heat transfer coefficient, $h_{t g}$, which is a function of convection and radiation heat transfer mechanisms.

\subsection{Optimised Average Seawater Temperature}

The seawater in the solar still basin experienced the radiation, convection and evaporation heat transfer processes. The water molecules evaporate whenever it received sufficient heat energy from the basin, forming water vapours and finally condensates to become the clean water. The comparison between the theoretical and experimental results of the average seawater temperature behaviour is shown in Figure 7.

From the theoretical model, prediction of the average seawater temperature for the first five hours achieved an insignificant error not more than 6.5\%. Whereas, the later part of the hours, theoretical prediction suffered significant $106.9 \%$. However, the overall distribution, the average significant error reaches a $21.9 \%$ as compared to the experimental result.

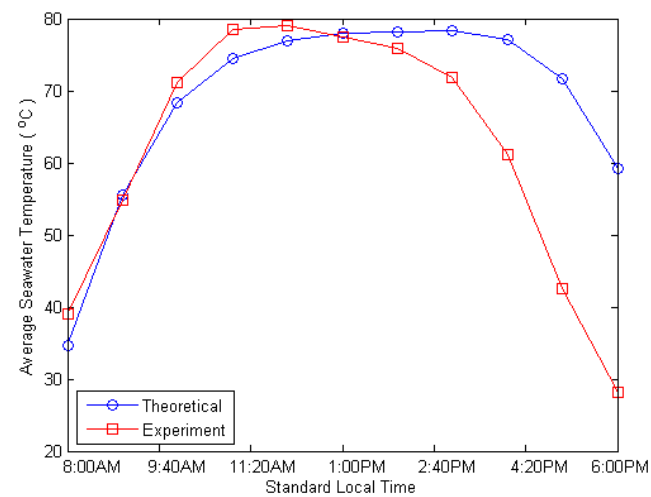

Figure 7. Theoretical and experimental seawater temperature, $T_{w}$.

The major set-back of the theoretical model could again be attributed to the much more varied distribution of the solar irradiance in the later parts of the hours and so the seawater absorptivity, $a_{w}$. Thus, the overall seawater heat transfer coefficient, $h_{t w}$ towards the later parts of the hours in a sunny day must be further modified to suit the characteristic distribution of the solar irradiance and so the temperature distribution of the heat transfer processes in the solar still.

\subsection{Optimised Average Basin Temperature}

The basin of the solar still is made of steel, which is homogeneous and highly conductive material is able to absorb all solar energy received and to transmit heat exchanges fast enough to the seawater due to high thermal conductivity. In this condition, basin behaviour is more linear in heat transfer processes over the material characteristics resulting a close-fit theoretical model and prediction. The exterior of solar still basin is well insulated with polystyrene and so no heat loss to surroundings is assumed for the model. The comparison of theoretical and experimental result is shown in Figure 8. 


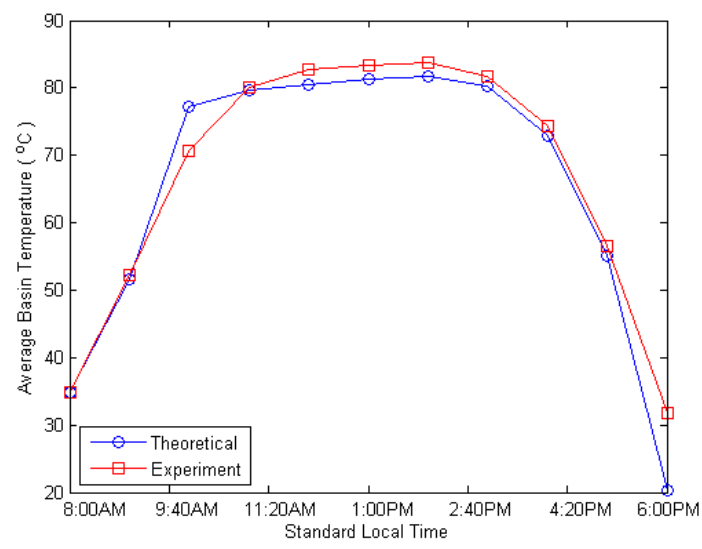

Figure 8 . Theoretical and experimental comparison of average basin temperature, $T_{b}$.

As a result, highly close prediction of average basin temperature is achieved by the theoretical model. Except for the ten o'clock in the morning, and the six o'clock in the evening that suffer a high error percentage of $9.4 \%$ and $36.3 \%$, respectively. As for the rest of the temperature distribution behviour, a mere error percentage of not more than $2.8 \%$ is achieved by the theoretical prediction compared to the experimental result. The simple yet effective stainless steel medium or material and a stable boundary condition could be the key to highly consistent prediction by a rigid and linearized theoretical model.

\subsection{Optimised Accumulated Clean Water Mass}

The comparison between theoretical and experimental average accumulated mass of clean water production is shown in Figure 9. In particular, the final outcome of efficient performance of a solar still is best evaluated based on the total amount of clean water production index at a cost for every litre.

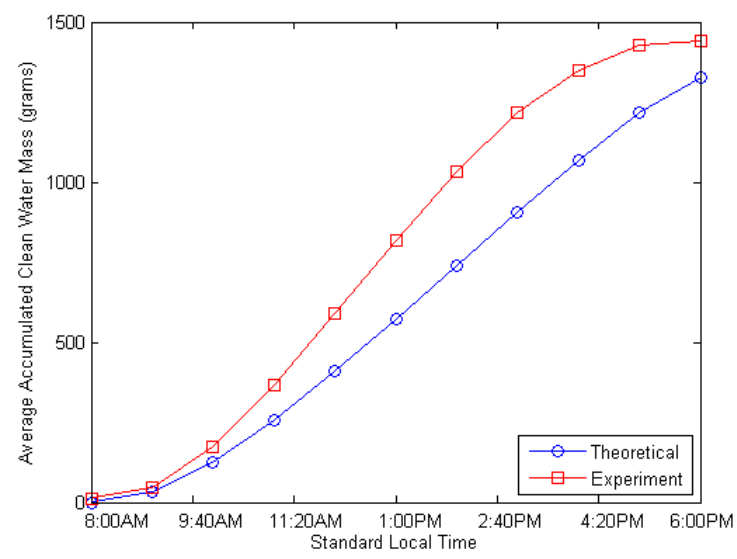

Figure 9. Theoretical and experimental comparison of average accumulated clean water mass.

The theoretical model is able to predict closely the amount of clean water produced in the early hours of the day up to the 10 o'clock time. However, theoretical and experimental trend start to diverged, and error percentage has shown to increase and reach $28.8 \%$ up to a maximum of $30.4 \%$ as the hours laps, see Figure 9.

Overall, losses and limitations of temperature distribution behaviour (earlier sections) during heat transfer processes between material properties, non-linearity, and idealization of the theoretical 
modelling could attribute to the inaccuracy of the theoretical model. Nevertheless, the theoretical model has predicted a similar trend for clean water production as the experimental result.

\subsection{Instantaneous Efficiency}

The instantaneous performance efficiency of a single slope solar still to produce a certain amount of clean water could be represented as the ratio of the evaporation heat flux over the solar irradiance, and calculated by using the theoretical model from (14). The Figure 10 illustrates the hourly instantaneous efficiency (percentage) of the theoretical and the experimental models.

The theoretical model has predicted a $1.52 \%$ instantaneous efficiency at the eight o'clock hour in the morning, and gradually increases to a maximum instantaneous efficiency of $14.17 \%$ at two o'clock hour in the afternoon, and again decreased to $3.67 \%$ at the end of the day. On the other hand, the experimental result has yield an instantaneous efficiency of $1.61 \%$ at the beginning of the experiment and increases to a maximum of $22.45 \%$ during the eleven o'clock hour in the morning, and to finally decreased to a mere $0.02 \%$ at the end of the experiment.

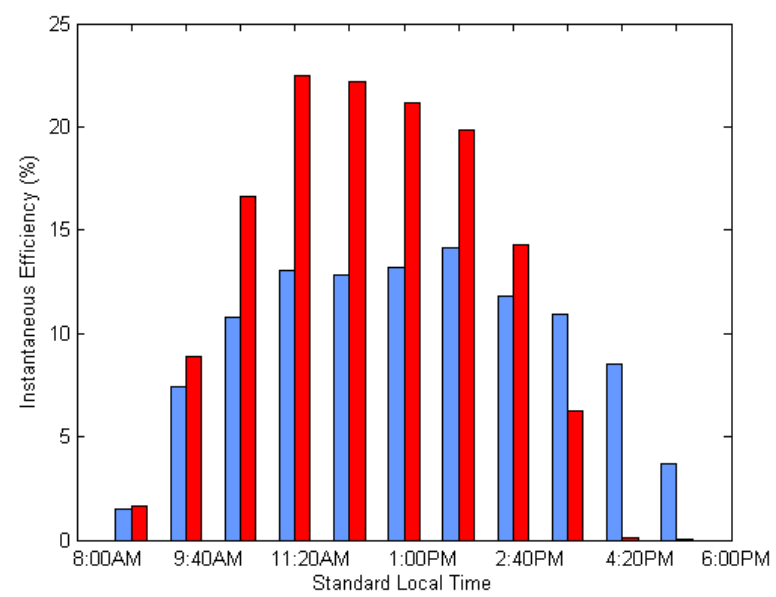

Figure 10. Theoretical and experimental comparison of solar still instantaneous efficiency.

From the instantaneous efficiencies of the experiment, for the eleven o'clock hour where the efficiency is a maximum, about $259.3 \mathrm{~W} / \mathrm{m}^{2}$ out of the $1155 \mathrm{~W} / \mathrm{m}^{2}$ of solar irradiance has been utilized by the solar still for the evaporation process of the seawater. The result is most satisfactory for a simple solar still design with no extra water heater or reflector devices to boost the heat transfer activities in the solar still.

Though, the instantaneous efficiency of theoretical model has predicted similar trend to the experimental, but the result has been poor. The cumulative losses from the temperature distribution prediction of the glass cover, seawater and basin all attributed to the theoretical instantaneous efficiency inaccuracy. Thus, the instantaneous efficiency of theory model could only improve if the prediction of the mass of clean water produced with respect to the temperatures behaviour of the still is improved [31]. 


\section{Conclusion}

The theoretical heat transfer principal behind the single slope solar still is established for modelling based on heat exchange processes of three major components of the solar still (glass cover, seawater and basin) and its surroundings. Radiation, convection, conduction, and evaporation of heat transfer processes are implemented in the theoretical model using the First-Law of Thermodynamics.

The theoretical model has shown to predict the experimental trend in the heat transfer temperature distribution processes of the solar still system. However, significant error is found in the theoretical prediction, particularly for the later hours of the afternoon, where solar irradiance is less uniform and intense as compared to the morning hours of the sunny day. In comparison, theoretical and experimental results found that theory model is able to predict solar still behaviours at early hours of the morning where the solar irradiance is intense and consistent.

In this respect, the sciences, engineering and technology have been explored to translate the challenges into a tangible topic on the single slope solar still that utilized the renewable solar energy for desalination of seawater to produce clean water. The single slope solar still, as a simple and effective water treatment device is found to be promising, safe, and user friendly for the applications in rural areas to support the basic needs of people.

\section{Acknowledgements}

The authors are thankful to the Ministry of Higher Education Malaysia for funding this project (Grant no. FRG0310-TK-1/2012) and the Unit Kajian Bahan dan Mineral, Faculty of Engineering, Universiti Malaysia Sabah for providing support and facilities.

\section{References}

[1] Esfahani, J.A, Rahbar, N. and Lavvaf, M. (2011). Utilization of Thermoelectric Cooling in a Portable Active Solar Still — An Experimental Study on Winter Days, Desalination 269, pp 198-205.

[2] Kumar, S., Tiwari, G. N. and Gaur, M. K. (2010). Development of Empirical Relation to Evaluate the Heat Transfer Coefficients and Fractional Energy in Basin Type Hybrid (PV/T) Active Solar Still, Desalination 250, pp 214-221.

[3] Fath, H. E., El-Samanoudy, M., Fahmy, K. and Hassabou, A. (2003). Thermal-Economic Analysis and Comparison Between Pyramid-Shaped and Single-Slope Solar Still Configurations, Desalination 159, pp 69-79.

[4] Mahdi, J. T. and Smith, B. E. (1994). Solar Distillation of Water Using a V-Trough Solar Concentrator with a Wick-Type Solar Still, Renewable Energy 5, pp 520-523.

[5] Aybar, H.S. (2006). Mathematical Modelling of an Inclined Solar Water Distillation System, Desalination 190, pp 63-70.

[6] Tripathi, R. and Tiwari, G. N. (2005). Effect of Water Depth on Internal Heat and Mass Transfer for Active Solar Distillation, Desalination 173(2), pp 187-200.

[7] Tiwari, G. N., Shukla, S. K. and Singh, I. P. (2003). Computer Modeling of Passive/Active Solar Stills by Using Inner Glass Temperature, Desalination 154(2), pp 171-185.

[8] Khalifa, A.J.N. and Ibrahim, H.A. (2009). Effect of Inclination of the External Reflector on the Performance of a Basin Type Solar Still at Various Seasons, Energy for Sustainable Development 13, pp 244-249. 
[9] Singh, B.P. (2011). Performance Evaluation of a Integrated Single Slope Solar Still with Solar Water Heater, MIT International Journal of Mechanical Engineering 1(1), pp 68-71.

[10] Dashtban, M. and Tabrizi. F.F. (2011). Thermal Analysis of a Weir-Type Cascade Solar Still Integrated with PCM Storage, Desalination 279, pp 415-422.

[11] Swetha, K. and Venugopal, J. (2011). Experimental Investigation of a Single Slope Solar Still Using PCM, International Journal of Research in Environmental Science and Technology 1(4), pp 30-33.

[12] Nafeya, A.S., Abdelkaderb, M., Abdelmotalip, A. and Mabrouk, A. A. (2000). Parameters Affecting Solar Still Productivity, Energy Conversion \& Management 41, pp 1797-1809.

[13] Badran, O. O. (2007). Experimental Study of the Enhancement Parameters on a Single Slope Solar Still Productivity, Desalination 209, pp 136-143.

[14] Dev, R. and Tiwari, G. N. (2009). Characteristic Equation of a Passive Solar Still, Desalination 245, pp 246-265.

[15] Badran, O.O. and Abu-Khader, M.M. (2007). Evaluating Thermal Performance of a Single Slope Solar Still, Heat Mass Transfer 43, pp 985-995.

[16] Samee, M.A., Mirza, U.K., Majeed, T. and Ahmad, N. (2007). Design and Performance of a Simple Single Basin Solar Still, Renewable and Sustainable Energy Reviews 11, pp 543-549.

[17] Rajamanickam, M. R. and Ragupathy, A. (2012). Influence of Water Depth on Internal Heat and Mass Transfer in a Double Slope Solar Still, 2nd International Conference on Advances in Energy Engineering (ICAEE2011) 14, pp 1701 - 1708.

[18] Tiwari, A.K. and Tiwari, G. N. (2006). Effect of Water Depths on Heat and Mass Transfer in a Passive Solar Still: In Summer Climatic Condition, Desalination 195, pp 78-94.

[19] Tiwari, A.K. and Tiwari, G. N. (2007). Thermal Modeling Based on Solar Fraction and Experimental Study of the Annual and Seasonal Performance of a Single Slope Passive Solar Still: The Effect of Water Depths, Desalination 207, pp 184-204.

[20] Khalifa, A.J.N. (2011). On the Effect of Cover Tilt Angle of the Simple Solar Still on its Productivity in Different Seasons and Latitudes, Energy Conversion and Management 52, pp 431-436.

[21] Murugavel, K. K., Chockalingam, K.K. and Srithar, K. (2008). Progresses in Improving the Effectiveness of the Single Basin Passive Solar Still, Desalination 220, pp 677-686.

[22] Phadatare, M. K., and Verma, S. K. (2007). Influence of Water Depth on Internal Heat and Mass Transfer in a Plastic Solar Still, Desalination 217(1), pp 267-275.

[23] Taamneh, Y., and Taamneh, M. M. (2012). Performance of Pyramid-Shaped Solar Still: Experimental Study, Desalination 291, pp 65-68.

[24] Ismail, B. I. (2009). Design and Performance of a Transportable Hemispherical Solar Still, Renewable Energy 34(1), pp 145-150.

[25] Abdullah, A. S. (2013). Improving the Performance of Stepped Solar Still, Desalination 319, pp 60-65.

[26] Shawaqfeh, A.T. and Farid, M.M. (1995). New Development in the Theory of Heat and Mass Transfer in Solar Stills, Solar Energy 55(6), pp 527-535.

[27] Kiam Beng Yeo, Kenneth Tze Kin Teo and Cheah Meng Ong. (2014). Temperature Distribution of Single Slope Solar Still by Finite Difference Method, Journal of Applied Sciences 14(22), pp 3101-3105.

[28] Badran, O.O. and Abu-Khader, M.M. (2007). Evaluating Thermal Performance of a Single Slope Solar Still, Heat Mass Transfer 43, pp 985-995.

[29] Yeo, K.K., Ong, C.M. and Teo, K.T.K. (2014). Heat Transfer Energy Balance Model of Single Slope Solar Still, Journal of Applied Sciences 14(23), pp 3344-3348.

[30] Omara, Z. M., Kabeel, A. E., Abdullah, A. S. and Essa, F. A. (2016). Experimental Investigation of Corrugated Absorber Solar Still with Wick and Reflectors, Desalination 381, pp 111-116.

[31] Abujazar, M.S.S., Fatihaha, S., Rakmi, A. R. and Shahrom, M. Z. (2016). The Effects of Design Parameters on Productivity Performance of a Solar Still for Seawater Desalination: A Review, Desalination 385, pp 178-193. 